\title{
Double Taxation Treaty Interpretation: \\ Lessons from a Case Down Under
}

I du Plessis*

\section{P.E.R}

Pioneer in peer-reviewed, open access online law publications

Author

Izelle du Plessis

\section{Affiliation}

Stellenbosch University

South Africa

Email idup@sun.ac.za

Date Submission

22 August 2019

Date Revised

11 November 2020

Date Accepted

11 November 2020

Date published

8 December 2020

Editor Dr G Viljoen

How to cite this article

Du Plessis I "Double Taxation

Treaty Interpretation: Lessons from

A Case Down Under" PER / PELJ

2020(23) - DOI

http://dx.doi.org/10.17159/1727-

3781/2020/v23i0a6840

\section{Copyright}

\section{DOI}

http://dx.doi.org/10.17159/1727-

3781/2020/v23i0a6840

\begin{abstract}
In the Australian case of Bywater Investments Ltd $v$ Commissioner of Taxation; Hua Wang Bank Berhad v Commissioner of Taxation (the Bywater case) the Australian High Court dealt with the question of whether certain companies were resident in Australia for income tax purposes. The majority answered this question by applying Australian domestic law. In a separate but concurring judgement, Gordon $\mathrm{J}$ also discussed the interpretation and application of the relevant double taxation treaty. This contribution analyses Gordon J's judgment to extract guidance from it for the South African courts on their interpretation of double taxation treaties.
\end{abstract}

It is submitted that South African courts should also follow the "first step" proposed by Gordon J when interpreting double taxation treaties. South African courts may find Gordon J's judgment "instructive" when dealing with the interpretation of the "place of effective management" concept in both domestic law and double taxation treaties. In his judgment Gordon $\mathrm{J}$ favours the goal of common interpretation and it is argued that South African courts should follow this example and explicitly support this notion in applicable cases. From Gordon J's judgment and the judgement in Krok $v$ Commissioner, South African Revenue Service, it is deduced that the positions in South Africa and Australia are similar in that the courts in both countries will be bound by the principles of Articles 31 and 32 of the Vienna Convention on the Law of Treaties when interpreting double taxation treaties. Moreover, Gordon J's judgment indicates that the domestic principles of interpretation should not be used in the interpretation of double taxation treaties. Recent South African cases have suggested that there are no differences between the South African domestic principles of interpretation and those contained in Articles 31 and 32 of the Vienna Convention on the Law of Treaties. This contribution submits that there are many similarities between the two, but that the rules are not exactly the same. South African courts should be aware of these differences and rather apply the rules of public international law, including those contained in the Vienna Convention on the Law of Treaties, when they interpret double taxation treaties. Gordon $\mathrm{J}$ specifically identifies the category of the Vienna Convention on the Law of Treaties in which he places the Commentary on the OECD Model Tax Convention, to rely on it for his interpretation of the relevant double taxation treaty. South African courts may well learn from this approach, to create more certainty in the process of interpreting a double taxation treaty.

\section{Keywords}

Double taxation treaty; interpretation; taxation; place of effective management. 


\section{Introduction}

Recently the Australian High Court delivered judgment in the case of Bywater Investments Ltd v Commissioner of Taxation; Hua Wang Bank Berhad $v$ Commissioner of Taxation (hereafter Bywater). ${ }^{1}$ The majority judgment dealt with the question of whether certain companies were resident in Australia for income tax purposes in terms of Australia's domestic laws. The minority judgment delivered by Gordon $\mathrm{J}$ reached the same conclusion as the majority in respect of the residency issue, but in addition discussed the interpretation and application of the relevant double taxation treaty (DTT).

The purpose of this contribution is to analyse the minority judgment and to determine whether this judgment can guide the South African courts in their interpretation of DTTs. In this regard particular focus will be placed on the interpretation of the concept of "place of effective management" (POEM). In South Africa this concept is used as one of the criteria to determine whether a person other than an individual is resident in South Africa. ${ }^{2}$ It is also used in many of South Africa's DTTs as a tie-breaker provision. In other DTTs it is used as one of the factors that revenue authorities will take into account when they endeavour to determine through mutual agreement where the person is resident for purposes of the DTT.

Like any other text, DTTs have to be interpreted. The approach to the interpretation of DTTs and the various difficulties associated with this exercise are addressed in many scholarly works ${ }^{3}$ and case law around the world. In South Africa courts have also grappled with some of these difficulties. ${ }^{4}$ In Bywater Australia's apex court has addressed some of these questions and thus a closer examination of the judgment is warranted.

Izelle du Plessis. BCom (Law) (Stell) LLB (Stell) LLM (Taxation) (UCT) LLD (Stell). Senior Lecturer, Department of Mercantile Law, Stellenbosch University, South Africa. E-mail: idup@sun.ac.za. ORCiD: https://orcid.org/0000-0002-6188-3973.

1 Bywater Investments Ltd $v$ Commissioner of Taxation; Hua Wang Bank Berhad $v$ Commissioner of Taxation 2016 HCA 45 (hereafter the Bywater case).

2 Section 1 of the Income Tax Act 58 of 1962, definition of "resident".

$3 \quad$ Examples include Baker Double Taxation Conventions para E; Avery Jones "Treaty Interpretation"; Edwardes-Ker Tax Treaty Interpretation; Ward et al Interpretation of Income Tax Treaties; Vogel and Rust "Introduction".

$4 \quad$ For example, Secretary for Inland Revenue v Downing 19754 SA 518 (A) (hereafter the Downing case); Commissioner for the South African Revenue Service $v$ Tradehold Ltd 20123 All SA 15 (SCA) (hereafter the Tradehold case); Krok v Commissioner, South African Revenue Service 20156 SA 317 (SCA) (hereafter Krok); Commissioner for the South African Revenue Service $v$ Van Kets 20123 SA 399 (WCC) (hereafter the Van Kets case). 
Australia is a useful jurisdiction for comparative purposes, because it shares a long history with South African tax law. The South African Income Tax Act was initially based on the income tax legislation enacted by an Australian state, New South Wales. ${ }^{5}$ Furthermore, the Australian "system of taxation has much in common with our own", ${ }^{6}$ and therefore the South African Supreme Court of Appeal has on numerous occasions looked to Australian decisions for guidance. ${ }^{7}$ Moreover the Bywater decision is itself of significance, since it is the first judgment by the highest court in Australia ${ }^{8}$ on the interpretation of DTT since Thiel $v$ Commissioner of Taxation (hereafter Thiel). ${ }^{9}$ Although the South African Supreme Court of Appeal has on two occasions interpreted DTTs after the adoption of the Constitution of the Republic of South Africa, 1996 (hereafter the Constitution), the Constitutional Court has never expressed an opinion on the matter. It is therefore submitted that the judgment in Bywater should be examined carefully to assess whether it may contain lessons for the South African courts regarding the interpretation of DTTs.

\section{The facts in Bywater}

In Bywater four companies were held liable for income tax in Australia on the basis that each of these companies was resident there. Although the facts pertaining to each company were not identical, there were many similarities. Two of the companies, Chemical Trustee and Derrin, were incorporated in the United Kingdom. Bywater was incorporated in the Bahamas and Hua Wang Bank Berhad in Samoa. Shares in the first three companies were held through nominee companies for JA Investments or MA Investments, both companies incorporated in the Cayman Islands. In respect of Bywater, the directors were a Mr Borgas, his wife and a firm of professional administrators. In the case of Chemical Trustee, the directors comprised of Mr Borgas, his wife and their son. Only Mr and Mrs Borgas

Jansen van Rensburg "History of Income Taxation in the Cape Colony"; Harris "Importing and Exporting Income Tax Law"; Broomberg 2008 BTR 291; Commissioner for Inland Revenue v Cactus Investments (Pty) Ltd 19991 SA 264 (T) 310 .

$6 \quad$ Richards Bay Iron \& Titanium (Pty) Ltd v Commissioner for Inland Revenue 19961 SA 311 (A) 317.

7 See e.g. Avenant $v$ Commissioner for South African Revenue Service 201678 SATC 343 (SCA); Richards Bay Iron \& Titanium (Pty) Ltd v Commissioner for Inland Revenue 19961 SA 311 (A) 317; Secretary for Inland Revenue $v$ Rile Investments (Pty) Ltd 19783 SA 732 (A). In Sentra-oes Koöperatief Bpk v Commissioner for Inland Revenue 19953 SA 197 (A) the court distinguished the facts before it from those in an Australian case.

8 Davies 2019 BIT 402.

$9 \quad$ Thiel $v$ Commissioner of Taxation 1990 HCA 37 (hereafter the Thiel case). 
were the directors of Derrin. Bywater, Chemical Trustee and Derrin argued that Borgas resided and operated in Switzerland and that central management and control ${ }^{10}$ of the relevant taxpayers was therefore in Switzerland. Furthermore, JA Investments and MA Investments were beneficially owned by Gould (of New South Wales, Australia) who made all the decisions. Borgas made no decisions and the apparent ownership structure and directorships by the Borgases and the professional administrators were fake or a facade. In the case of Hua Wang Bank Berhad, the rights of shareholders to vote or demand a poll were suspended until certain debentures were redeemed. Effectively the debenture holders controlled the company. The debentures were held by JA Investments. The directors of Hua Wang Bank Berhad were all (save for one) employees of a company providing professional administrative services. Although these directors performed their duties in Samoa, they acted only on directions from Gould. These directors made no commercial decisions and provided only what was called "back-office" services.

The majority of the High Court of Australia found that Gould had usurped the functions of the boards of all the companies mentioned above and that he took all the important decisions in respect of the companies in Australia. It held that the meetings of the boards were window-dressing and constituted rubberstamping decisions already taken by Gould in Australia. Thus, the companies were resident in Australia for domestic income tax purposes.

\section{The minority judgment}

In his separate but concurring judgment, Gordon $\mathrm{J}$ held that Hua Wang Bank Berhard was centrally managed and controlled in Australia and thus resident in Australia for domestic income tax purposes.

More importantly, Gordon J also investigated where Bywater, Chemical Trustee and Derrin's POEM was located. POEM was used as a tie-breaker in DTTs between Australia and the United Kingdom on the one hand and between Australia and Switzerland on the other. The court assumed that Chemical Trustee and Derrin were resident (for domestic law purposes) in the United Kingdom and that Bywater was resident (for domestic law

10 In terms of the definition of "resident" in s 6(1) of the Income Tax Assessment Act, 1936, a company that is not incorporated in Australia, but which carries on business in Australia and has its central management and control in Australia, is an Australian resident. The parties conceded that in this case if the companies had its central management and control in Australia, its POEM would also be in Australia. The court found in para 6 that the concession had been properly made. 
purposes) in Switzerland. Since the court had found that the companies were also resident in Australia for domestic law purposes, the provisions of the tie-breaker became applicable. In each of the relevant agreements, if a company were resident in both contracting States (as the court had found or assumed it was), it would be regarded as a resident for purposes of the DTT only in the State in which it had its POEM. ${ }^{11}$ Thus, where both States claimed that the company was a resident, the tie-breaker provision applied to determine the company's residence for treaty purposes.

Importantly, the court pointed out that the first step in the process was to ascertain what and how much of an international instrument, such as the relevant DTTs, Australian law required to be implemented. Thus, the court had to establish the extent to which Australian law adopts, qualifies, or modifies the instrument. According to the court, this first step is critical because,

... as a matter of statutory interpretation, there is a distinction between circumstances where [DTTs] have been enacted into Australian law and circumstances where provisions of an Act draw on a treaty which has not been enacted into Australian law. ${ }^{12}$

The court found that since these particular DTTs were set out in full in legislation and given the force of law, the text of the DTT should bear the same meaning in the relevant domestic legislation as it bears in the DTT. ${ }^{13}$ However, the court warned that if the terms of the DTT were interpreted strictly in accordance with domestic principles of statutory interpretation, there would be a significant risk that the DTT would be interpreted differently even though other countries had adopted the same instrument. The purpose of DTTs, which is to prevent double taxation across two jurisdictions, would be hindered if they were interpreted in a way that could result in conflicting outcomes between the two States in question. ${ }^{14}$ The court therefore concluded that the principles applicable to the interpretation of international instruments, namely those set out in the Vienna Convention on the Law of Treaties (hereafter the Vienna Convention), ${ }^{15}$ must be applied.

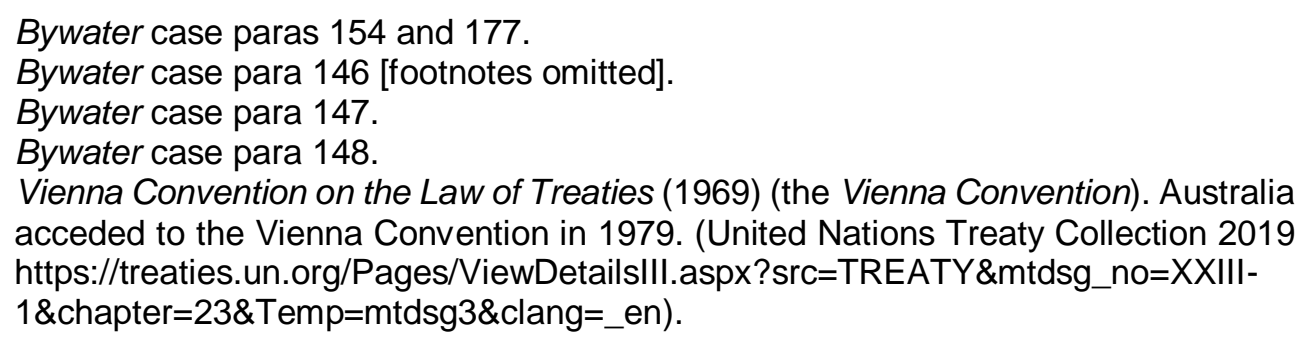
acceded to the Vienna Convention in 1979. (United Nations Treaty Collection 2019 https://treaties.un.org/Pages/ViewDetailsIII.aspx?src=TREATY\&mtdsg_no=XXIII$1 \&$ chapter $=23 \&$ Temp $=$ mtdsg3\&clang=_en). 
The court noted that the DTT between Australia and Switzerland was entered into before the Vienna Convention came into force. ${ }^{16}$ Although the Vienna Convention does not apply retrospectively, the court confirmed that its provisions reflected customary international law and that it was, therefore, appropriate to refer to the Vienna Convention when interpreting the Australian-Switzerland DTT. ${ }^{17}$

The court first investigated the application of the DTT between Australia and the United Kingdom. Gordon J approached the interpretation of POEM in this treaty by referring to the Vienna Convention, which states that: ${ }^{18}$

A treaty shall be interpreted in good faith in accordance with the ordinary meaning to be given to the terms of the treaty in their context and in the light of its object and purpose.

He held that the express terms of the phrase POEM oblige one to enquire further than the formal place where the formal organs of a company might be located. He also referred to the purpose of a DTT, namely to avoid double taxation; that is, taxation of the same person in respect of the same activity by two States. The court held that the "key determinant" for taxation in terms of the relevant DTT was residency, and that the purpose of the tie-breaker provision was to break the deadlock where the other provisions of the DTT did not determine which State could impose tax. The court consequently held that

... its ability to break a deadlock would be seriously undermined were it construed so as to be limited to an inquiry about the location of the formal organs of a company. ${ }^{19}$

Gordon $\mathrm{J}$ also relied on Article 32 of the Vienna Convention, which permits reference to supplementary means of interpretation to confirm a meaning resulting from the application of Article 31 of the Vienna Convention, and the Australian High Court's decision in Thiel, ${ }^{20}$ to refer to the Commentary on the Organization for Economic Cooperation and Development Model Tax Convention (hereafter the OECD MTC). ${ }^{21} \mathrm{He}$ then quoted the relevant Commentary as it then read. The judge observed that the Commentary explained that although POEM is "ordinarily" to be found where the directors

\footnotetext{
Bywater case para 149.

Bywater case para 181.

Article 31(1) of the Vienna Convention.

Bywater case para 166.

Thiel v Commissioner of Taxation 1990 HCA 37.

Each version of the Organization for Economic Cooperation and Development Model Tax Convention (OECD MTC) is accompanied by commentary, drafted by the OECD's Committee on Fiscal Affairs.
} 
make their decisions, all relevant facts and circumstances must be taken into account. ${ }^{22}$ On the facts of the case, the court held that although Chemical Trustee and Derrin were incorporated in the United Kingdom and their ultimate shareholders were located there, the board of directors formally met in Switzerland, but ultimately, Mr Gould was the person who controlled and owned these two companies. Mr Gould took the key management and commercial decisions in Australia and thus the POEM was in Australia.

Returning to the DTT between Australia and Switzerland in Bywater, it also used POEM as a tie-breaker. The court found that Mr Borgas only formally implemented decisions that were taken by Mr Gould in Australia. The court, therefore, held that

... it is a nonsense to say that Mr Borgas was 'effectively managing' each entity from Switzerland. The 'place of effective management' was with $\mathrm{Mr}$ Gould in Australia. ${ }^{23}$

\section{The issues raised and possible lessons for South Africa}

\subsection{Starting point: Status of treaty}

Gordon $\mathrm{J}$ indicated that the first step in the interpretation process was to ascertain to what extent the DTT formed part of Australian law. It is submitted that the same would be true for DTTs in South Africa. In South Africa, DTTs are incorporated into the Income Tax Act 58 of 1962 (hereafter the Income Tax Act) via section 231 of the Constitution and section 108(2) of the Income Tax Act. Thus, once a DTT has been approved by both houses of parliament and has been gazetted, it forms part of South African law. ${ }^{24}$ It is thus important to note that the whole of a DTT forms part of the Income Tax Act. ${ }^{25}$

However, in Commissioner for the South African Revenue Service $v$ Tradehold (hereafter Tradehold), ${ }^{26}$ the court approved of the method set out in Ostime (Inspector of Taxes) v Australian Mutual Provident Society, ${ }^{27}$

\footnotetext{
$22 \quad$ Bywater case para 169.

23 Bywater case para 184.

24 Krok case para 24; Van Kets case paras 18 and 25; ITC 1878201577 SATC 349 para 5.

25 The issue of a conflict between the Income Tax Act and the provisions of a DTT falls outside the scope of this contribution.

26 Commissioner for the South African Revenue Service $v$ Tradehold Ltd [2012] 3 All SA 15 (SCA).

27 Ostime (Inspector of Taxes) v Australian Mutual Provident Society 19593 All ER 245.
} 
namely "the first step in any interpretive inquiry is to ascertain where in the scheme of the double tax agreement the relevant tax falls, and then to consider whether the tax can be imposed consistently with the obligations undertaken thereunder."28 It is submitted that taking the "first step" described in Tradehold is possible only once it has been ascertained that the DTT forms part of the Income Tax Act, the step described by Gordon J as "the first step". In fact, in Tradehold the court referred to section 108(2) of the Income Tax Act earlier in its judgment and noted that the DTT, once brought into operation, has the effect of law. ${ }^{29}$ Thus the court in Tradehold followed Gordon J's "first step" although it described its next step of ascertaining where in the scheme of the DTT tax falls as its first step. It is submitted that South African courts, therefore, should continue to apply Gordon J's first step and thereafter ascertain where in the DTTs scheme the relevant tax falls.

\subsection{Meaning of POEM in domestic legislation and $D T T^{30}$}

In Bywater Gordon J used the fact that the DTT forms part of the relevant legislation as the justification for his statement that the "transposed text should bear the same meaning in the domestic statute as it bears in the [DTT]." ${ }^{31}$ In attributing a meaning to the text in the DTT, he favours a common interpretation and proposes the application of the Vienna Convention. Both of these points are addressed in the paragraphs below. The focus for now is on the fact that Gordon $\mathrm{J}$ is of the view that where the same concept is used in a domestic statute and a DTT, the meaning of the concept in the domestic statute should have the same meaning as in the DTT.

In South Africa the question has been raised regarding the manner in which the concept POEM should be interpreted, since it is used in both the Income Tax Act and some DTTs as a tie-breaker provision. Does the concept have the same meaning in the two different instruments?

In 1997 the Katz Commission recommended that South Africa adopt POEM as the test for the domestic residence of persons other than natural persons. It is clear from this Commission's report that they recommended that a

\footnotetext{
$28 \quad$ Tradehold case para 20.

29 Tradehold case paras 15-16.

30 The purpose of this paragraph is not to discuss the actual meaning of the POEM concept. Rather, it is aimed at discussing the narrow question of whether the concept should bear the same meaning in the Income Tax Act as it has in South African DTTs.

$31 \quad$ Bywater case para 147 [footnotes omitted].
} 
meaning similar to that associated with the term in Article 4(3) of the OECD MTC be adopted in South Africa. To this end the Commission proposed that the term POEM be defined. ${ }^{32}$ The latter recommendation was never implemented and the term thus remains undefined in the Income Tax Act. However, one can deduce that the Katz Commission intended POEM to have the same meaning in both the Income Tax Act and DTTs entered into by South Africa.

Some authors agree with the opinion of the Katz Commission, ${ }^{33}$ while others are of the view that the two have different functions and should likewise have different meanings. ${ }^{34}$ In The Oceanic Trust Co Ltd v Commissioner for the South African Revenue Service (hereafter Oceanic Trust) ${ }^{35}$ the court did not discuss the question of whether the meaning of the term POEM in the Income Tax Act, with which it was confronted, was the same as the meaning of the term under a DTT. However, the court did adopt the test laid down in the United Kingdom case of Commissioners for Her Majesty's Revenue and Customs $v$ Smallwood ${ }^{\beta 6}$ in relation to POEM, a case which dealt with the meaning of POEM in a DTT context. Arguably, one could deduce that the court by implication indicated that the same meaning should apply in the Income Tax Act as in a DTT.

Naturally, the Constitution plays a determining role in how legislation should be interpreted. It provides that when interpreting any legislation, every court must prefer any reasonable interpretation of the legislation that is consistent with international law over any alternative interpretation that is inconsistent with international law. ${ }^{37}$ The DTTs entered into by South Africa are a source of international law ${ }^{38}$ and as such a reasonable interpretation of the Income Tax Act that is consistent with South Africa's DTTs should be preferred. Since the term POEM is used in most of South Africa's DTTs, ${ }^{39}$ it is

32 Katz Commission 1997 http://www.treasury.gov.za/publications/other/katz/5.pdf para 6.1.2.1.

33 E.g., Van der Merwe 2002 SA Merc LJ 79.

34 E.g., Olivier and Honiball International Tax 42, although their view is based on an Interpretation note that has since been replaced; Hattingh "South Africa" 725.

35 The Oceanic Trust Co Ltd v Commissioner for the South African Revenue Service 74 SATC 127 (hereafter the Oceanic Trust case). Commissioners for Her Majesty's Revenue and Customs v Smallwood 2010 EWCA Civ 778. Section 233 of the Constitution of the Republic of South Africa, 1996 (the Constitution).

$38 \quad$ Strydom "International Law Making" 68.

39 The Multilateral Convention to Implement Tax Treaty Related Measures to Prevent Base Erosion and Profit Shifting (2017), to which South Africa is a party, may replace POEM as the tie-breaker provision in existing DTTs. However, this treaty has not made it through the parliamentary process of $s 231$ of the Constitution yet and has 
submitted that the term POEM in the Income Tax Act should be interpreted in a way that is consistent with the term POEM used in South Africa's DTTs. Arguably, the fact that a DTT forms part of the Income Tax Act supports this point. ${ }^{40}$ Thus, the same term in a statute is presumed to have the same meaning. ${ }^{41}$

It is submitted that South African courts will regard the judgment of Gordon $\mathrm{J}$ in Bywater as "instructive"42 when interpreting the POEM concept, thereby attaching a similar meaning to it in the Income Tax Act as it has in South Africa's DTTs.

\subsection{Common interpretation}

Vogel and Rust describe common interpretation as the interpretation of a DTT in a way that is most likely to be accepted in both contracting States. ${ }^{43}$ Their justification for a common interpretation is that Article 31(1) of the Vienna Convention requires a DTT to be interpreted in the light of its objects and purpose. The purpose of a DTT is to allocate tax claims equally between the two relevant contracting States, and this purpose can be achieved only if the DTT is interpreted consistently by the courts in both States. EdwardesKer refers to the requirement of good faith in Article 31(1) of the Vienna

therefore not become law in South Africa. Therefore, South Africa's DTTs have not been amended by this treaty.

$40 \quad$ Krok case para 24; Van Kets case para 25.

41 Du Plessis "Statute Law and Interpretation" para 347. However, if the context differs, this presumption no longer applies. It has been argued that the context differs between the Income Tax Act and a DTT. See for example Hattingh "South Africa" 725. Although the context may differ to a certain extent, it is submitted that the definition of "resident" in the Income Tax Act draws the DTT context into the Income Tax Act, by providing that if a person is deemed to be exclusively a resident of another state in terms of a DTT, that person is not a resident in South Africa. The DTT therefore forms part of the context of the Income Tax Act. Furthermore, although some argue that the aim of the DTT is to "determine 'best residency' from a choice of at least two residencies" (Gutuza 2012 SA Merc LJ 424), it is submitted that the aim of the Income Tax Act is also to determine a single residence for an entity (see Van der Merwe 2002 SA Merc LJ 88). The purpose of the DTT and that of the Income Tax Act can therefore be reconciled, namely to determine one residency for a person other than a natural person. Interpreting the term POEM in the Income Tax Act in this fashion, the more sensible interpretation is that which attributes the same meaning to POEM as it has in terms of DTTs entered into by South Africa (Natal Joint Municipal Pension Fund v Endumeni Municipality 20124 SA 593 SCA paras 18-20).

$42 \quad K r o k$ case para 38 described a United Kingdom case as "instructive". According to Jansen van Rensburg the judgments of foreign courts are not binding on South African courts (Jansen van Rensburg South African Perspective on the Meaning of "Beneficial Ownership" 255).

$43 \quad$ Vogel and Rust "Introduction" 41-42. 
Convention to substantiate why a common interpretation must be followed. ${ }^{44}$

Gordon $\mathrm{J}$ in Bywater seems to support the notion of common interpretation. He points to the purpose of DTTs, which is to prevent double taxation across two jurisdictions. This purpose would be frustrated if they were interpreted in a way that could result in conflicting outcomes between the two States in question. When interpreting DTTs, recent South African decisions also seem to favour a common interpretation, although perhaps not expressly. For example, in Tradehold, the court stated that

... the term must be given a meaning that is congruent with the language of the DTT having regard to its object and purpose..$^{45}$

Furthermore, the court in that case specifically considered the meaning which both State parties intended the specific term to bear. ${ }^{46} \mathrm{~A}$ further example may be found in ITC 1878, where the court arguably regarded the

$44 \quad$ Edwardes-Ker Tax Treaty Interpretation para 5.02. The influence of an article in a DTT similar to art 3(2) of the OECD MTC should be borne in mind when the goal of common interpretation is pursued. This article, which is included in some form in all of South Africa's DTTs, provides that "[a]s regards the application of the Convention at any time by a Contracting State, any term not defined therein shall, unless the context otherwise requires or the competent authorities agree to a different meaning pursuant to the provisions of Article 25, have the meaning that it has at that time under the law of that State for the purposes of the taxes to which the Convention applies, any meaning under the applicable tax laws of that State prevailing over a meaning given to the term under other laws of that State". If art 3(2) applies to a given term, it may result in the two states attaching different meanings to the same term. Jansen van Rensburg points out that when art 3(2) applies, the states have agreed "the possibility of diverse outcomes in the interpretation of the same term" (Jansen van Rensburg South African Perspective on the Meaning of "Beneficial Ownership"126).

$45 \quad$ Tradehold case para 23 [own emphasis].

$46 \quad$ Tradehold case para 24. It is interesting to contrast para 24 in the Tradehold case with the unreported decisions of the Tax Court in Cape Town in ABC (Pty) Ltd v Commissioner for the South African Revenue Services (Tax Court of South Africa, Cape Town) (unreported) case number 14287 of 12 June 2019 (hereafter the $A B C$ case). In the latter case the court refused to allow evidence regarding the intention of the state parties to a DTT, because it contravened the parol evidence rule. Yet in the Tradehold case the court referred to the parties' intention. It is submitted that the apparent contradiction can be easily explained. In the $A B C$ case the court did not allow the evidence of the state parties about how they understood the words used in the DTT. The court used the wording of the DTT to determine its meaning. In the Tradehold case the court likewise considered the words of the DTT to determine its meaning and from these words, the court determined what was intended. In other words, the court will use the words of the DTT to interpret it. However, the parties may not testify to the court what they intended, in order for the court to interpret the words. Therefore, the parol evidence rule does not conflict with the idea of a common interpretation. In the latter, the court interprets a DTT in a way that is most likely to be accepted in both contracting states, but the states do not testify as to their intention. 
Commentary to the OECD MTC as a means of achieving a common interpretation by stating that the Commentary seeks to minimise the different interpretations that may be placed on the same words by the different States. ${ }^{47}$ Jansen van Rensburg is also of the opinion that South African courts normally apply a common interpretation, but makes the point that South African courts have also been prepared to depart from such an interpretation. ${ }^{48}$

It is submitted that there is sufficient justification for South African courts to apply a common interpretation in relevant cases where the interpretation of DTTs is called for ${ }^{49} \mathrm{It}$ is submitted that South African courts should follow the example of Gordon $\mathrm{J}$ and explicitly support this notion in applicable DTT cases.

\subsection{The Vienna Convention}

Gordon $\mathrm{J}$ relied on the principles of the Vienna Convention to interpret the relevant DTTs in Bywater. These principles were used in the interpretation of the Australia-Switzerland DTT, even though the Vienna Convention itself did not apply.

South Africa has not ratified the Vienna Convention and in that sense, the Vienna Convention itself does not apply to South Africa. However, the Supreme Court of Appeal (SCA) in Krok v Commissioner, South African Revenue Service (hereafter Krok) ${ }^{50}$ stated that Articles 31 and 32 of the Vienna Convention are binding on South Africa as rules of customary international law. The Constitution provides that customary international law is law in South Africa unless it is inconsistent with the Constitution or an Act of parliament. ${ }^{51}$ South African courts will, therefore, be bound to apply these rules of the Vienna Convention when interpreting any DTT. It can consequently be deduced that the positions in South Africa and Australia are similar in that the courts in both countries will be bound by the principles of Articles 31 and 32 of the Vienna Convention when interpreting DTTs.

ITC 1878201577 SATC 349 para 15. However, the court departed from the interpretation provided by the Commentary and gave its own interpretation of the relevant phrase. Jansen van Rensburg South African Perspective on the Meaning of "Beneficial Ownership" 224.

See further Jansen van Rensburg South African Perspective on the Meaning of "Beneficial Ownership" 219-224 for cogent arguments regarding the use of common interpretation by South African courts in DTT cases.

$50 \quad$ Krok case para 27.

51 Section 232 of the Constitution. 
However, one may question whether South African courts have indeed applied these principles. There are many examples of cases where the South African courts when considering DTTs did not even mention the Vienna Convention. ${ }^{52}$ However, since the Krok-decision two judgments of the Tax Court have referred to the relevant provisions of the Vienna Convention..$^{53}$ It is hoped that this trend will continue and that all judgments in which South African courts interpret DTTs will rely on these principles of the Vienna Convention.

\subsection{Domestic principles of statutory interpretation versus the Vienna Convention}

In the part of his judgment dealing with common interpretation, Gordon $\mathrm{J}$ warned that if the terms of the DTT were interpreted strictly in accordance with domestic principles of statutory interpretation, there would be a significant risk that the DTT would be interpreted differently even though other countries had adopted the same instrument. This statement raises the question of whether domestic principles of interpretation should be used in the interpretation of DTTs. Gordon $\mathrm{J}$ is clearly of the view that they should not.

However, in Krok the SCA stated that Articles 31 and 32 of the Vienna Convention "are essentially no different from those [rules] generally applied by our courts in construing statutes and agreements." 54 In the unreported judgment of the Tax Court in Cape Town, the court stated that: ${ }^{55}$

The question to be determined therefore requires this court to apply the legal principles relating to the interpretation of written agreements and more specifically those concluded in the realm of international law. The starting point is South African domestic law and then if appropriate private international law of which the primary source is the Vienna Convention on the Law of Treaties of 1969.

It is submitted that the reference to "private" international law in the quote above, is probably a minor error, which should rather read "public" international law since the Vienna Convention falls within the realm of public international law. However, very little turns on this description. It is the

52 Volkswagen of South Africa (Pty) Ltd v Commissioner for the South African Revenue Service 70 SATC 195 (the Volkswagen case), Commissioner for the South African Revenue Service $v$ Tradehold Ltd 20123 All SA 15 (SCA); Grundlingh v Commissioner for the South African Revenue Service 200972 SATC 1; ITC 1878 201577 SATC 349.

53 ITC 1914201880 SATC 472 and the $A B C$ case.

$54 \quad$ Krok case para 27.

$55 \quad A B C$ case para 19. 
court's method of referring first to domestic law and only later and only "if appropriate" referring to international law and the Vienna Convention which is problematic. Later in the judgment the court also relies on Krok for the statement that the principles applicable to the interpretation of statutes and agreements in South African law are the same as those applied in international law. ${ }^{56}$

Although the SCA and the Tax Court regard the rules of the Vienna Convention and those regarding the interpretation of domestic law and agreements to be the same, Jansen van Rensburg points out that there are at least some differences between the two. One of the examples of such differences is that the goal of common interpretation is not present when domestic statutes are interpreted. ${ }^{57}$ It is therefore submitted that there are indeed many similarities ${ }^{58}$ between the rules of the Vienna Convention and the rules regarding the interpretation of domestic statutes, but the rules are not exactly the same. South African courts should be alive to these differences and rather apply the rules of public international law, including those contained in the Vienna Convention, when they interpret DTTs. In this regard the Tax Court's statement that international law and the Vienna Convention will be referred to only if appropriate cannot be supported.

\subsection{The use of the Commentary}

Interestingly, Gordon $\mathrm{J}$ relied on Article 32 of the Vienna Convention as authority for his reference to the Commentary. This Article allows the use of "supplementary means of interpretation", but only to confirm a meaning determined through the application of Article 31, or to determine the meaning when the interpretation according to Article 31 leaves the meaning ambiguous or obscure, or leads to a result which is manifestly absurd or unreasonable. Therefore, supplementary means of interpretation may be used only in the limited circumstances referred to. In this case Gordon $\mathrm{J}$ relied on the Commentary to confirm the meaning of the POEM concept that he had already determined.

Many courts around the world agree that Article 32 of the Vienna Convention may be relied on to justify reference to the Commentary when interpreting a DTT ${ }^{59}$ and thus Gordon J's judgment cannot be faulted on this

\footnotetext{
$56 \quad A B C$ case para 33.

57 Jansen van Rensburg South African Perspective on the Meaning of "Beneficial Ownership" 225.

58 See Burt 2017 BTCLQfn. 37 for a discussion of the similarities.

59 Avery Jones "Treaty Interpretation" para 3.11.4.
} 
score. However, the real question regarding the Commentary is whether it may be relied on as part of the Article 31 interpretation process. The reason for this debate is that if the Commentary falls within Article 32 only, it may be referred to only in the limited circumstances outlined above. ${ }^{60}$ Gordon $\mathrm{J}$ did not have to address this point in his judgment and followed the judgment in Thie ${ }^{61}$ which also relied on Article 32 of the Vienna Convention.

The OECD Commentary does not fit easily into any of the possibilities found in Articles 31 and 32 of the Vienna Convention. ${ }^{62}$ Moreover, which one of these possibilities should be preferred is the subject of scholarly debate. ${ }^{63}$ However, the courts in many States use the OECD Commentary to interpret DTTs, but the exact basis on which they do so is unclear and not frequently explicitly stated. ${ }^{64}$ In this sense the judgment in Bywater is an exception, because it explicitly relied on Article 32 of the Vienna Convention.

South African courts have not been consistent in their reference to the Commentary. Some courts have not mentioned the Commentary, even though it may have been relevant. ${ }^{65}$ Other courts have indeed referred to the Commentary. ${ }^{66}$ The Tax Court has even adopted an interpretation that is contrary to that set out in the Commentary, because in the court's view the Commentary does not take into account certain words in the OECD MTC. ${ }^{67}$ No South African court has yet pronounced on the basis upon which they referred to the Commentary, or attempted to categorise it within the Vienna Convention. ${ }^{68}$ It is submitted that the Australian courts' approach in Thiel and Bywater, which states explicitly in which category of the Vienna Convention it places the Commentary in order to rely on it is the preferred approach, even though it is the exception when compared to the courts of many other States. It is submitted that this approach provides some

60 $\quad$ Avery Jones "Treaty Interpretation" para 3.11.2.1.

$61 \quad$ Thiel $v$ Commissioner of Taxation 1990 HCA 37.

62 Baker Double Taxation Conventions para E12; Avery Jones "Treaty Interpretation" para 3.11; Ward et al Interpretation of Income Tax Treaties 29; Jansen van Rensburg South African Perspective on the Meaning of "Beneficial Ownership" 118. Avery Jones "Treaty Interpretation" para 3.11; Baker Double Taxation Conventions para E12; Garbarino Judicial Interpretation of Tax Treaties paras I.76-I.88; Ward et al Interpretation of Income Tax Treaties 18. Baker Double Taxation Conventions para E.12; Arnold 2010 BIT 8; Mössner 2010 BIT 16 17; Harris and Oliver International Commercial Tax 34. E.g., the Volkswagen case; Grundlingh $v$ Commissioner for the South African Revenue Service 200972 SATC 1; ITC 1544199254 SATC 456 (T); ITC 17352002 64 SATC 455; Tradehold case; Oceanic Trust case; ITC 1914201880 SATC 472 E.g., the Downing case; ITC 1503199053 SATC 342 (T); the Krok case.

$67 \quad$ ITC 1878201577 SATC 349. Ownership" 244. 
certainty to taxpayers and tax administrators regarding the process that the court will apply when interpreting a DTT. South African courts may well learn from this Australian example.

\section{Conclusion}

Like the approach of Gordon $\mathrm{J}$ in Bywater, South African courts will also, when applying a DTT, as a first step determine the extent to which the DTT forms part of South African law. The second step in the interpretive process is to ascertain where in the DTTs scheme the relevant tax falls. It is submitted that these two steps were also applied in Tradehold.

In Bywater Gordon $\mathrm{J}$ was of the view that words should bear the same meaning in the domestic statute as they bear in a DTT. South African courts will find this judgment instructive and will interpret the POEM concept by attaching a similar meaning to it in the Income Tax Act as it has in South Africa's DTTs. Oceanic Trust may be an example of where the court has done exactly this.

Gordon $\mathrm{J}$ in Bywater seems to support the notion of a common interpretation of DTTs. Arguably, recent South African cases have done the same, although they have not referred to this notion explicitly. It is submitted that South African courts should follow the example of Gordon $\mathrm{J}$ and explicitly support this notion in applicable DTT cases.

As the court in Bywater confirmed, the Articles in the Vienna Convention dealing with the interpretation of treaties are customary international law. In South Africa the SCA came to the same conclusion in Krok, and both States are therefore bound to apply these rules when interpreting DTTs. Decisions after Krok have referred to the Vienna Convention and this should be welcomed. However, South African courts should take heed of the fact that the rules regarding interpretation in the Vienna Convention and those used to interpret domestic legislation are not identical. Although there may be significant overlap in these two sets of rules, it is submitted that South African courts should interpret DTTs in accordance with the principles of public international law, like those contained in the Vienna Convention.

The courts in many States refer to the OECD Commentary on the interpretation of DTTs, but the exact basis on which they do so is uncertain and often it is not mentioned explicitly. However, the court in Bywater based its reliance on the Commentary on Article 32 of the Vienna Convention. Although this may limit the use of the Commentary, the court should be 
commended for unambiguously stating the basis on which it relied on the Commentary. South African courts have not always relied on the Commentary and where they have, they have not always mentioned the basis. It is submitted that South African courts should follow Gordon J's example and state explicitly why they rely on the Commentary.

The judgment of Gordon $\mathrm{J}$ in Bywater may provide valuable guidance to South African courts regarding the interpretation of DTTs. Since South African courts have not always been consistent in some aspects of their interpretation of DTTs, such guidance on issues of principle should be regarded as "instructive" and therefore followed.

\section{Bibliography}

\section{Literature}

Arnold 2010 BIT

Arnold BJ "The Interpretation of Tax Treaties: Myth and Reality" 2010 BIT $1-15$

Avery Jones "Treaty Interpretation"

Avery Jones J "Treaty Interpretation" in Vann R (eds) Global Tax Treaty Commentaries (IBFD Amsterdam 2019) 1-93

Baker Double Taxation Conventions

Baker P Double Taxation Conventions: A Manual on the OECD Model Tax Convention on Income and on Capital $3^{\text {rd }}$ ed (Sweet \& Maxwell London 2002)

Broomberg 2008 BTR

Broomberg EB "The Legacy of UK Tax Law in South Africa" 2008 BTR291303

\section{Burt 2017 BTCLQ}

Burt K "The OECD Commentaries: On what Legal Basis and to what Extent are they Relevant to Tax Treaty Interpretation?" 2017 BTCLQ 5-28

Davies 2019 BIT

Davies J "Precedent and Law - Australia" 2019 BIT 402-407

Du Plessis "Statute Law and Interpretation"

Du Plessis LM "Statute Law and Interpretation" in Joubert WA (ed) Law of South Africa (Juta Cape Town 2001) 211 - 417 
Edwardes-Ker Tax Treaty Interpretation

Edwardes-Ker M Tax Treaty Interpretation (PhD-thesis Queen Mary and Westfield College University of London 1994)

Garbarino Judicial Interpretation of Tax Treaties

Garbarino C Judicial Interpretation of Tax Treaties: The Use of the OECD Commentary (Edward Elgar London 2016)

Gutuza 2012 SA Merc LJ

Gutuza T "Has Recent United Kingdom Case Law Affected the Interplay Between 'Place of Effective Management' and 'Controlled Foreign Companies'?" 2012 SA Merc LJ 424-437

Harris "Importing and Exporting Income Tax Law"

Harris $P$ "Importing and Exporting Income Tax Law: The International Origins of the South African Income Tax Act" in Hattingh J, Roeleveld JJ and West C (eds) Income Tax in South Africa: The First 100 Years, 19142014 (Juta Cape Town 2016) 2-24

Harris and Oliver International Commercial Tax

Harris P and Oliver D International Commercial Tax (Cambridge University Press Cambridge 2010)

Hattingh "South Africa"

Hattingh PJ "South Africa" in Maisto G (eds) Residence of Companies under Tax Treaties and EC Tax Law (IBFD Amsterdam 2009) 603-752

Jansen van Rensburg "History of Income Taxation in the Cape Colony" Jansen van Rensburg E "The History of Income Taxation in the Cape Colony: A Story of Dangerous Beasts and Murderous Fathers" in Hattingh J, Roeleveld JJ and West C (eds) Income Tax in South Africa: The First 100 Years, 1914-2014 (Juta Cape Town 2016) 25-53

Jansen van Rensburg South African Perspective on the Meaning of "Beneficial Ownership"

Jansen van Rensburg E A South African Perspective on the Meaning of "Beneficial Ownership" in Article 10 of the OECD Model Tax Convention on Income and Capital in the Context of Conduit Company Treaty Shopping (LLD-thesis University of Pretoria 2017)

Mössner 2010 BIT

Mössner J "Klaus Vogel Lecture 2009 - Comments" 2010 BIT 16-19 
Olivier and Honiball International Tax

Olivier L and Honiball M International Tax: A South African Perspective $5^{\text {th }}$ ed (Siberink Cape Town 2011)

Strydom "International Law Making"

Strydom H "International Law Making as an Attribute of State Sovereignty" in Strydom H (ed) International Law (Oxford University Press Oxford 2014) $63-104$

Van der Merwe 2002 SA Merc LJ

Van der Merwe B "Residence of a Company - The Meaning of 'Effective Management"' 2002 SA Merc LJ 79-92

Vogel and Rust "Introduction"

Vogel K and Rust A "Introduction" in Reimer E and Rust A (eds) Klaus Vogel on Double Taxation Conventions (Wolters Kluwer Alphen aan den Rijn 2015) 1-72

Ward et al Interpretation of Income Tax Treaties

Ward DA et al The Interpretation of Income Tax Treaties with Particular Reference to the Commentaries of the OECD Model (International Fiscal Association Kingston 2005)

\section{Case law}

$A B C$ (Pty) Ltd v Commissioner for the South African Revenue Services (Tax Court of South Africa, Cape Town) (unreported) case number 14287 of 12 June 2019

Avenant $v$ Commissioner for South African Revenue Service 201678 SATC 343 (SCA)

Bywater Investments Ltd v Commissioner of Taxation; Hua Wang Bank Berhad v Commissioner of Taxation 2016 HCA 45

Commissioner for Inland Revenue $v$ Cactus Investments (Pty) Ltd 19991 SA 264 (T)

Commissioner for the South African Revenue Service v Tradehold Ltd 2012 3 All SA 15 (SCA)

Commissioner for the South African Revenue Service v Van Kets 20123 SA 399 (WCC) 
Commissioners for Her Majesty's Revenue and Customs v Smallwood 2010 EWCA Civ 778

Grundlingh v Commissioner for the South African Revenue Service 200972 SATC 1

ITC 1503199053 SATC 342 (T)

ITC 1544199254 SATC 456 (T)

ITC 1735200264 SATC 455

ITC 1878201577 SATC 349

ITC 1914201880 SATC 472

Krok v Commissioner, South African Revenue Service 20156 SA 317 (SCA)

Natal Joint Municipal Pension Fund v Endumeni Municipality 20124 SA 593 (SCA)

Ostime (Inspector of Taxes) v Australian Mutual Provident Society 19593 All ER 245

Richards Bay Iron \& Titanium (Pty) Ltd v Commissioner for Inland Revenue 19961 SA 311 (A) 317

Secretary for Inland Revenue v Downing 19754 SA 518 (A)

Secretary for Inland Revenue v Rile Investments (Pty) Ltd 19783 SA 732 (A)

Sentra-oes Koöperatief Bpk v Commissioner for Inland Revenue 19953 SA $197(A)$

The Oceanic Trust Co Ltd v Commissioner for the South African Revenue Service 74 SATC 127

Thiel v Commissioner of Taxation 1990 HCA 37

Volkswagen of South Africa (Pty) Ltd $v$ Commissioner for the South African Revenue Service 70 SATC 195 


\section{Legislation}

Constitution of the Republic of South Africa, 1996

Income Tax Act 58 of 1962

Income Tax Assessment Act, 1936

\section{International instruments}

Multilateral Convention to Implement Tax Treaty Related Measures to Prevent Base Erosion and Profit Shifting (2017)

Organization for Economic Cooperation and Development Model Tax Convention (last updated 2017)

Vienna Convention on the Law of Treaties (1969)

\section{Internet sources}

Katz Commission 1997 http://www.treasury.gov.za/publications/ other/katz/5.pdf

Commission of Inquiry into Certain Aspects of the Tax Structure of South Africa 1997 5th Interim Report of the Commission of Inquiry into Certain Aspects of the Tax Structure of South Africa: Basing the South African Income Tax System on the Source or Residence Principle - Options and Recommendations http://www.treasury.gov.za/publications/other/katz/5.pdf accessed 17 October 2020

United Nations Treaty Collection 2019 https://treaties.un.org/ Pages/ViewDetailsIII.aspx?src=TREATY\&mtdsg_no=XXIII-1\&chapter $=23 \&$ Temp $=$ mtdsg3\&clang $=\_$en

United Nations Treaty Collection 2019 Chapter XXIII: Law of Treaties Vienna Convention on the Law of Treaties https://treaties. un.org/Pages/ViewDetailsIII.aspx?src=TREATY\&mtdsg_no=XXIII-1\& chapter=23\&Temp=mtdsg3\&clang=_en accessed 25 July 2019 


\section{List of Abbreviations}

$\begin{array}{ll}\text { BIT } & \text { Bulletin for International Taxation } \\ \text { BTCLQ } & \text { Business Tax and Company Law Quarterly } \\ \text { BTR } & \text { British Tax Review } \\ \text { DTT } & \text { Double taxation treaty } \\ \text { MTC } & \text { Model Tax Convention } \\ \text { OECD } & \text { Organization for Economic Cooperation and } \\ & \text { Development } \\ \text { POEM } & \text { Place of effective management } \\ \text { SA Merc LJ } & \text { South African Mercantile Law Journal } \\ \text { SCA } & \text { Supreme Court of Appeal }\end{array}$

